\title{
Congenital papillomas and papillomatoses associated with the Human Papilloma Virus (HPV) - report on 5 cases
}

\author{
Pathology Department of UFF, Pathology Department of UNIRIO, Virology Department of UFRJ,
} Clinical Pathology of IFF/FIOCRUZ - Rio de Janeiro, Brazil

\begin{abstract}
The authors present a study of five cases of vulvar congenital papillomas and papillomatoses in stillborns and neonates dead upon birth. The studied material was collected from five necropsies. The histopathological evaluation showed hyperkeratosis, acanthosis, papillomatosis, perinuclear haloes, and nuclear abnormalities. In three of the cases, the electron microscopy identified nuclear and cytoplasmatic viral particles ranging from 40 to $60 \mathrm{~nm}$ in size, compatible with HPV. The immunohistochemical study of those lesions showed nuclear and cytoplasmatic positivity. The authors concluded that the presence of viral particles suggestive of HPV added to the immunopositivity indicated the possibility of viral infection.
\end{abstract}

UNITERMS: Congenital Papilloma. HPV. Papillomatosis.

\section{INTRODUCTION}

$\mathrm{T}$ The Human Papilloma Virus (HPV) is associated to benign and malignant lesions in the skin and mucosas (1-4). One of the ways the infection presents itself is the condyloma acuminata, which can be induced by types 6 , $11,16,18$, and 54 (3). The appearance of anogenital papillomas in children is not frequent. Since 1982, only 34 cases of infant condyloma acuminata were published (5). The ways of transmission indicated were perinatal, family contact, and sexual abuse.

The congenital infection by HPV was suggested in 1978, by Tang et al. (6), when they reported a condyloma acuminata case of a newborn whose mother had a lesion during pregnancy,

In the 80 's, the number of publications concerning the condyloma acuminata in children grew significantly (7-20).

\author{
Address for correspondence: \\ Eliane Pedra Dias \\ Rua Barão de Itapagipe, 401 - bloco 2 - ap. 201 - Tijuca \\ Rio de Janeiro/RJ - Brasil - CEP 20261-000
}

In these studies, the main mode of transmission continued to be sexual abuse and perinatal infection. Types 6 and 11 are predominant in the infant lesions, however, type 2 was also indicated as an etiologic agent. Besides, the identification of types 16 and 18 , both having an oncogenic potential, reinforces all the more the importance of fetal and infant infection.

Pregnancy seems to favor the manifestation of the condyloma acuminata since it occurs more in pregnant women than in the general population (21-23).

Up until the end of the 80 's, the major concern about women that presented condylomata acuminata during delivery, was the transmission to the fetus during birth and the possible appearance of laryingeal papillomatosis lesions (24-27). Several studies show that the treatment of the active infection during pregnancy protects the fetus from infection and so a cesarean delivery is no longer necessary (28-31). These studies, however, do not represent long term monitoring of the children.

Some researchers have dedicated themselves to finding definite proof of the congenital infection by the HPV (3235 ). Tsend et al. (36) stand out for their studies on vaginal cervical cells and the peripheral blood of 52 pregnant women (third quarter) and blood from the cord of the respective conceptus. They found HPV16 DNA in $6(11.5 \%)$ specimens of vaginal cervical cells and in $9(17.3 \%)$ of the peripheral 
maternal blood. The analysis of the cord blood of the respective conceptuses was positive in 7 .

The vulvar papillomatosis is an entity recently found in adults. Its origin and clinical significance is still controversial (37-41). It was described for the first time in 1982 and defined as fine scaly projections found in the vulvar vestibule $(38,39)$. There are still doubts concerning the true nature of this frequent vulvoscopic finding, with a wide range of identification of the viral DNA $(37,38,41)$. There are no reports of the occurrence of similar lesions in fetuses or newborns.

The diagnosis of the congenital infection is done by the $\mathrm{HPV}$ and its fetal effects is an important contribution not only for the study of biological behavior, which opens new perspectives for research, but also for medical practice where the approach to condyloma patients, particularly children and pregnant women, should be reviewed.

\section{MATERIAL AND METHODS}

The macro and microscopical skin alterations on a phallic projection of a malformed stillborn, suggestive of a cytopathic effect by the HPV, led us to review some cases in which we already had observed similar alterations in the genital area.

Therefore, we performed a review study of five cases, on human tissue included in paraffin, selected from the necropsies of two stillborns and three neonates, all of which were female. Of the two who were malformed, one had multiple malformations, and a decreased kidney was selected for the purpose of reviewing morphological alterations previously considered to be nephric hypoplasia and dysplasia.

\section{Histopathologic Exam}

A histopathological exam was performed on the five cases. Slides were stained with Hematoxylin-Eosin, using the following criteria to evaluate the skin with genital lesions: a) hyperkeratosis, acanthosis, and papillomatosis; b) perinuclear haloes and nuclear abnormalities; c) dermal inflammatory infiltrate. The identified abnormalities were classified according as light, moderate, or accentuated severity.

Histological cuts in the cortical and medullar regions of the reduced kidney were reviewed for the purpose of looking for abnormalities compatible with the inflammatory process that could justify an alteration in size.

\section{Ultramicroscopical Exam}

It was performed on three of the five cases $(1,2$, and 4$)$. The samples were collected from the genital lesions and the altered kidney, at the level of the cortical region (case 4). The selection was based on the intensity of the abnormalities identified in the epidermis and in the nephric parenchyma. Paraffin was removed and the material was reprocessed for inclusion in resin (SPURR). After the inclusion, we performed semi-fine and ultra-fine cuts for examination on a Phillips 301 electron microscope.

\section{Immunohistochemical Exam}

An immunohistochemical exam was performed in the five cases, with "Monoclonal Papillomavirus HPV 16, L1 MAB 885" (Chemicon).

Lesion cuts without immune serum and normal skin cuts from the newborn in which immune serum was applied were used as negative references. Material obtained from a uterine cervix infected by HPV was used as a positive reference.

\section{RESULTS}

The cases studied presented, among other things, external genital papillomatosis lesions (figure 1). The main clinical data of the mothers can be seen on table 1. In the material selected for the study, we identified the following aspects (table 2):

\section{Optical Microscopy}

Case 1: Papilloma with epidermis presenting moderate hyperkeratosis, acanthosis, and papillomatosis and cell with

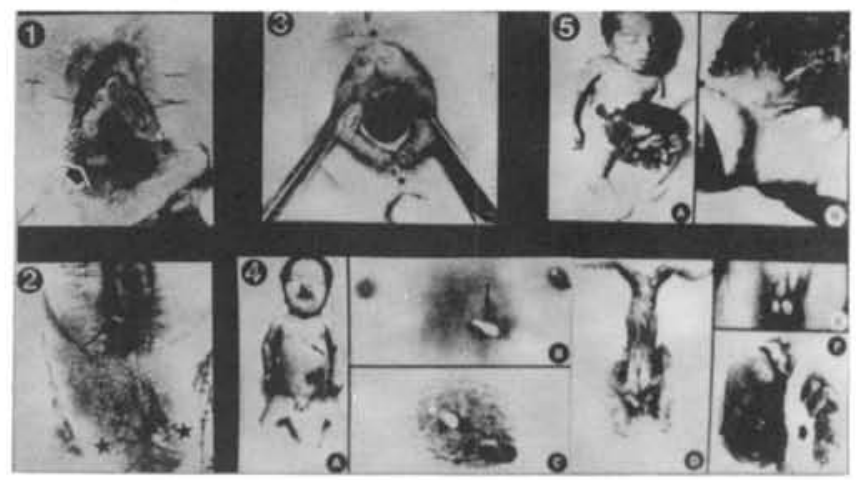

FIGURE 1 - Macroscopic Aspect of the Vulvar Lesions:

1-Case 1: polyp-like formation in the vaginal introitus.

2. Case 2: small polyp in vaginal introitus () and vulva/ perineum dermis with papillomatosis (*).

3- Case 3: discrete vulvar papillomatosis.

4-Case 4: vulva papillomas (e), chest (b), and areola (c), harelip (a), bi-cornificated uterus (d) and renal hypoplasia (f).

5- Case 5: Gastrochisis (a) with genitalia absent (b) and phallic projection (). 
Table 1

Main data regarding the conceptuses examined by necropsy.

\begin{tabular}{lllllllll}
\hline CN & Age & P/D & PP & PB & L & $C$ & $N$ & PI \\
\hline 1 & 37 & VIIINI & VI molar & PSHD & $\begin{array}{l}\text { meconium } \\
\text { and circular }\end{array}$ & Sb & NI & AP \\
\hline 2 & $?$ & V/IV & NSp & AH gemelary & $\begin{array}{l}\text { F1-NSp } \\
\text { F2-crossed }\end{array}$ & NN & Nol & PV? \\
\hline 3 & 31 & IV/III & DM & gemelary & $\begin{array}{l}\text { F1-PM } \\
\text { F2-PM }\end{array}$ & NN & Nol & IV \\
\hline 4 & 35 & IIII & NSp & $\begin{array}{l}\text { stop in growth } \\
\text { at 6 mo. }\end{array}$ & difficult & NN & BI & NE \\
\hline 5 & $?$ & $?$ & $?$ & $\begin{array}{l}\text { contact w/ } \\
\text { rubella }\end{array}$ & difficult & $\begin{array}{l}\text { SF } \\
\text { Sb }\end{array}$ & Nol & AP \\
\hline
\end{tabular}

$\mathrm{CN}=$ Case number $/ \mathrm{P} / \mathrm{D}=$ Pregnancies/Deliveries $/ \mathrm{PP}=$ Previous pregnancies $/ \mathrm{PB}=$ Pre-delivery

$\mathrm{L}=$ Labor / C=Conceptus / N=Necropsy / $\mathrm{Pl}=$ Placenta / Sb=Stillborn

PSHD=Pregnancy Specific Hypertension Disease / $\mathrm{Nl}=$ Nonspecific inflammation

$\mathrm{AP}=\mathrm{Ascending}$ placentitis $/ \mathrm{NSp}=\mathrm{No}$ special features $/ \mathrm{AH}=\mathrm{Artery}$ hypertension $/ \mathrm{F}=\mathrm{Fetus}$

$\mathrm{NN}=$ Neonate dead / Nol=No inflammation / $\mathrm{PV}=$ Proliferating vilositis / $\mathrm{DM}=$ Diabetes mellitum

$\mathrm{PM}=$ Premature / IV =Intervilositis / MF=Malformed / $\mathrm{Bl}=$ Bacterial infection / NE=Not examined

thickened capsule was observed on the cuts from the left kidney, peri-glomerular and peri-tubular fibrosis, with mononuclear inflammatory infiltrate and few neutrophils. These abnormalities would suggest an aggression to the nephric parenchyma, followed by fibrosis and a reduction in the nephric size.

Case 5: Instead of a well defined genitalia, the fetus had a phallic projection, coated with squamous mucosa and a cistic formation covered with squamous epitheliocyte, containing keratin.

We identified, on the squamous epithelium hyperkeratosis, irregular acanthosis and moderate papillomatosis (figure $2.5 \mathrm{~A}$ ). We noticed numerous cells with $\mathrm{PNH}$, nuclei portraying

perinuclear haloes $(\mathrm{PNH})$ in the more superficial layers (figure 2.1).

The nuclei were larger than normal for the superficial layer. They were oval or with a "flattened" aspect, well defined, occasionally fusiform and rarely binuclear. The superficial dermis showed ectasis and slight mononuclear inflammatory infiltrate, predominantly peri-vascular.

Case 2: Moderate cutaneous hyperkeratoses, acanthosis, and accentuated papillomatosis, epithelial hyperplasia with numerous cells with PNH, particularly in the intermediary and superficial layers, with nuclei portraying a "flattened" aspect, multilobed or fusiform (figure 2.2). Dermis with congested vessels and surrounded by a moderate quantity of mononucleated inflammatory cells.

Case 3: Vaginal epithelium with hyperplasia and cytoplasmatic vacuoles, due to glycogenic deposit. The skin presented slight and moderate hyperkeratosis, moderate and focal acanthosis, light papillomatosis and areas with PNH and oval nuclei, sometimes "flattened" or fusiform. In the dermis, vascular ectasis and areas of light mononuclear inflammatory infiltrate (figure 2.3)

Case 4: Epidermis of the polypoid lesion with hyperkeratosis and moderate acanthosis, accentuated papillomatosis and areas of cells with $\mathrm{PNH}$ and oval nuclei, colored in excess, fusiform or "flattened"; found in the intermediary and superficial layers (figure 2.4 ). The presence of moderate dermal inflammatory infiltrate was noted, formed by mononuclear leukocytes, predominately perivascular. A an increase in size, with light hyperchromasia, oval, "flattened" in some areas, fusiform or binucleated (figure 2.5 B). In the subjacent conjunctive tissue the vessels presented ectasis and, in some areas, were involved by mononuclear inflammatory cells.

\section{Immunohistochemical}

The cases $1,2,4$, and 5 presented epidermic immunopositivity for anti-HPV $16 \mathrm{~L} 1$.

The brownish granulations were identified, predominantly in the cytoplasm of the cells of the intermediate and superficial layers. Nuclear marking, though dispersed, was present. Case three showed rare brownish granulations, and was considered to be negative.

\section{Electron Microscopy}

The ultrafine cuts of the skin in cases 1,2, and 4 showed, in the epidermic cells, viral precursors, $27 \mathrm{~nm}$ in diameter located in the nucleus; and whole viral particles, with an average diameter of $50 \mathrm{~nm}$ located in the cytoplasm and nucleus. In the tissue of the kidney (case four), viral particles similar to those of the skin were found located in the nucleus and cytoplasm of the tubular epithelial cells (figure three), different from the dense fibrillar and fibroblast population, where we did not see viral particles. 


\section{DISCUSSION}

The genital worts are lesions that have been recognized since antiguity and referred to by many Greek and Roman writers (42). Until 1954 the mechanism of transmission was still not clear, the viral etiology was only established in 196842 and was further investigated only after became associated to the vulval carcinoma (43). The potential of fetal infection of some viruses is well known. The possibility of HPV being one of these viruses has been described in the last few years (32-36).

In our report of the five cases of congenital papillomas and papillomatosis, identified in stillborns and newly borns dead after a short period of time, during the initial necropsy the possibility of a viral lesion was not considered, except in the last case, in which a necroscopy exam was done in 1991. In this way, it became a triggering factor for the re-evaluation of the other cases.

The histopathological aspects observed in the lesions that were studied, correspond and are classically described as being associated to the injection by the HPV. In all the cases we observed epidermic abnormalities, such as, hyperkeratosis, acanthosis, papillomatoses and perinuclear haloes similar to the Koylocitosis (44-46). In the lesions we studied, the vacuolated cells showed aspects very similar to the ones described in the literature, with ample and well-defined perinuclear haloes, involving various aspects of nuclei: with a single or double nucleus, increased in size, oval, fusiform, with condensed and granulated chromatin, with central clear areas and peripheral chromatin.

In all of the vulval lesions submitted to the ultramicroscopy study, we identified viral particles. In spite of the artifacts consequent to the reprocessing of material included in paraffin. Some authors have demonstrated that its

Table 2

Main data from macroscopic, histopathology, immunohistochemical and ultramicroscopical evaluation of the vulvar lesions.

\begin{tabular}{llllllllll}
\multicolumn{10}{c}{ Optical Microscopy } \\
\cline { 2 - 6 } & $\mathrm{MC}$ & $\mathrm{Hk}$ & $\mathrm{AC}$ & $\mathrm{Pp}$ & $\mathrm{PNH}$ & $\mathrm{Nu}$ & $\mathrm{I}$ & IHC & EM \\
\hline 1 & $\mathrm{P}$ & $\mathrm{M}$ & $\mathrm{M}$ & $\mathrm{M}$ & ++ & + & L/Mn & Ip & VP \\
2 & $\mathrm{P} / \mathrm{Pp}$ & $\mathrm{M}$ & $\mathrm{S}$ & $\mathrm{S}$ & +++ & ++ & $\mathrm{M} / \mathrm{Mn}$ & Ip & VP \\
3 & $\mathrm{Pp}$ & $\mathrm{L}$ & $\mathrm{M}$ & $\mathrm{L}$ & + & + & L/Mn & - & NS \\
4 & $\mathrm{P}$ & $\mathrm{M}$ & $\mathrm{M}$ & $\mathrm{S}$ & +++ & +++ & $\mathrm{M} / \mathrm{Mn}$ & Ip & VP \\
5 & $\mathrm{P}$ & $\mathrm{M}$ & $\mathrm{M}$ & $\mathrm{M}$ & ++ & + & L/Mn & Ip & NS \\
\hline
\end{tabular}

$\mathrm{CS}=$ Case $/ \mathrm{MC}=$ Macroscopic conclusions / $\mathrm{P}=$ Papilloma $/ \mathrm{Hk}=$ Hyperkeratosis $/ \mathrm{AC}=\mathrm{Acanthosis}$ $\mathrm{Pp}=$ Papillomatosis / $\mathrm{PNH}=$ Perinuclear halo $/ \mathrm{L}=$ Light $/ \mathrm{M}=$ Moderate $/ \mathrm{S}=$ Severe $\mathrm{Nu}=$ Nuclear alterations $/ \mathrm{I}=$ Inflammation $/ \mathrm{Mn}=$ Mononuclear $/ \mathrm{IHC}=$ Immunohistochemical $\mathrm{EM}=$ Electron microscopy / +=Degree / NS=Not selected case / VP=Virus particles Ip=Immunopositivity possible to identify the viral particles and their characteristics, and the approximate size of $50 \mathrm{~nm}$ support the compatibility with the HPV (47-50). In case 4, the presence of peritubular, periglomerular and interstitial fibrosis associated to an inflammatory infiltrate, represent abnormalities that justify the nephric decrease in size. The identification of viral particles in tubular cells confirms the association of the abnormalities to the HPV, however, it does not make possible an etiologic association, since the HPV may have infected the abnormal nephric tissue This raises some questions, such as, the path of infection. In this case we could not prove that the viruses infected the kidney by hematogenous spread, since the amniotic liquid could have been infected via ascendens. Studies for viral identification in other malformations or tissues reachable only hematogenically are required.

The studies that use the IHQ techniques to reveal the presence of HPV antigen, indicate marked nuclei are a standard of positivity (50-54). All these studies were performed on the lesions of adult patients, and though there are technical variations and variations and in the results, the expressive nuclear marking always being present. Padayache (53), in 1987, published the results of their studies on oral papillomas. It describes, along with positive and negative groups, a group with $9 \%$ of doubtful cases, with cells with cytoplasmatic immunopositivity exclusively or in the nucleus and cytoplasm. The identification of discontinued areas of the nuclear membrane, though the possibility of artifact should be considered, and the complete particles found in the cytoplasm in the cases of congenital vulvar lesions, may explain the cytoplasmatic marking by immunohistochemical (IHQ), justifying the scarce nuclear marking. In the reference groups, the epidermic marking was expressive only in case five, which was repeated together with the negative references, immunopositivity was shown only in the lesion cut with immune serum. The positive reference that was used showed the expected nuclear marking.

Considering that the studies of lesions were done on stillborns and dead neonates, it can be affirmed that the infection happened intra-uterus, though the hematologic or ascendant spread could be discussed.

The studies about condyloma show that the evolution is unpredictable: some cases resolve spontaneously, others that recur, and others persist and can be associated to the development of carcinomas $(28-30,43,55)$. The factors involved in the determination of evolution by the HPV are still not completely clear. Anyway, the HPV type, the 


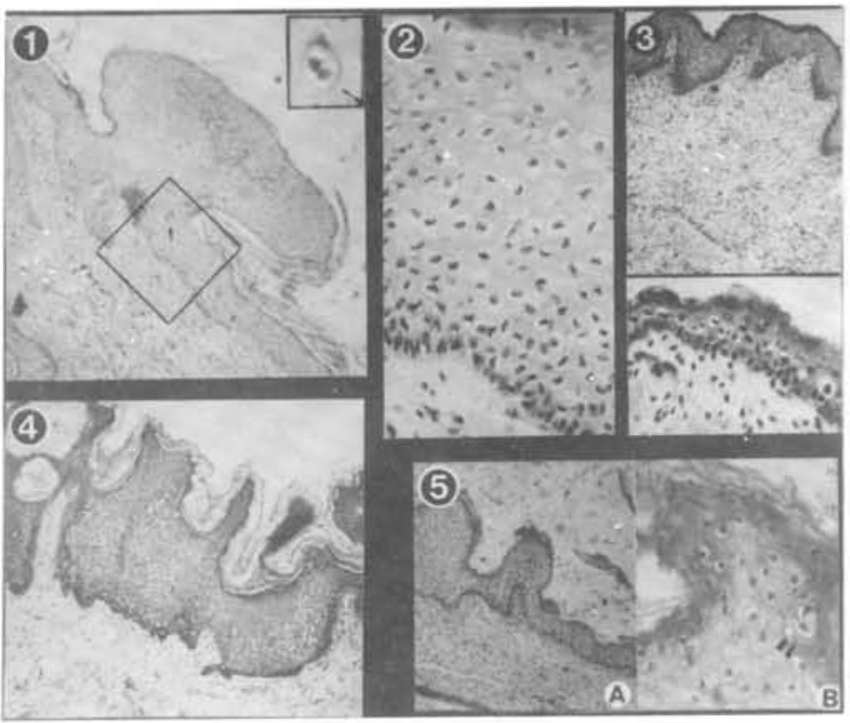

FIGURE 2 - Histopathological Aspects of the Vulvar Lesions: 1 - Case 1; 2 - Case 2; 3-Case 3; 4 - Case 4; 5 - Case 5; Al cases show, in different degrees: hyperkeratosis, acanthosis; perinuclear halos associated to irregular formations; nuclear hyperchromatism and binucleation ().

immunological status of the host, as well as genetic factors, are involved (56). Considering still, that pregnancy is a period particularly susceptible to the appearance of condylomata acuminata and cervical lesions, it is probable that the HPV type, the intensity of the lesion, the time of evolution, and the stage of pregnancy in which the maternal infection occurs, maybe some of the factors involved in the occurrence of fetal infection and in the determination of its severity and consequences.

Resulting morphological alterations of the congenital infection may not be present at birth, since a 6-8 month incubation period has to be taken into account. The lesions identified months after birth, reported by some authors $(5,15,16)$, can be the expression of an intra-uterine infection.

In 1974, Barcellos et al. (57), after studying cytohistologically 195 macroscopically normal uterine cervixes of infants, newborns, and fetuses, identified dysplastic cellular atypias in the squamous mucosa in some cases and inquired, "Why would these pathological abnormalities exist in a normal fetus, newborn, and infants?". The recent evidences of congenital infection by the HPV indicate the possibility that the dysplastic abnormalities correspond to the viral infection.

The intra-uterine fetus infection by the HPV raises some questions. It is known that many women present the latent infection $(3,58-60)$, that there is a relation between the HPV type and the anatomical site of the lesions $(61,62)$ and the evolution that seems to vary according to the host's particular characteristics $(62,63)$. Would these aspects be valid for a fetus infection? Is there a moment in which the fetus is more susceptible to infection? Would a more efficient fetus immunological response cause the lesions not to appear? Can the infection by the HPV be a cause of spontaneous abortion?

In the congenital infection by the HPV, the cytopathic consequences should, similiarly to other bodily areas, vary with the type of virus and pregnant woman's immunological conditions. Thus, an ample spectrum of possibilities is opened that can vary from non apparent infection to severe abnormalities in the fetal morphogenesis and influence on the morbidity and death.

Therefore, evidences are adding up to show that the HPV, besides being specific to humans, infecting the skin and mucosal membranes, being sexually transmittable, infecting fetuses at the moment of birth, and being transmitted by nonsexual contact, probably at some moment of its biological cycle disseminates itself via ascendants and/or hematogenically and, in pregnant women, crosses the placental barrier and causes fetal infection.

For the same reason the lesions have not drawn attention before, we believe that other similar situations have occurred and that the incidence of genital papilloma or the infection in other areas of the skin, is greater than what is described in literature. It is possible that as obstetricians, pediatricians, and pathologists start giving more attention to the fetuses' genitalia and skin, the papillomas and the papillomatoses will be more apparent.

The histopathological abnormalities classically described as being compatible with the infection by the HPV in adults, are present in congenital papillomas and papillomatoses.

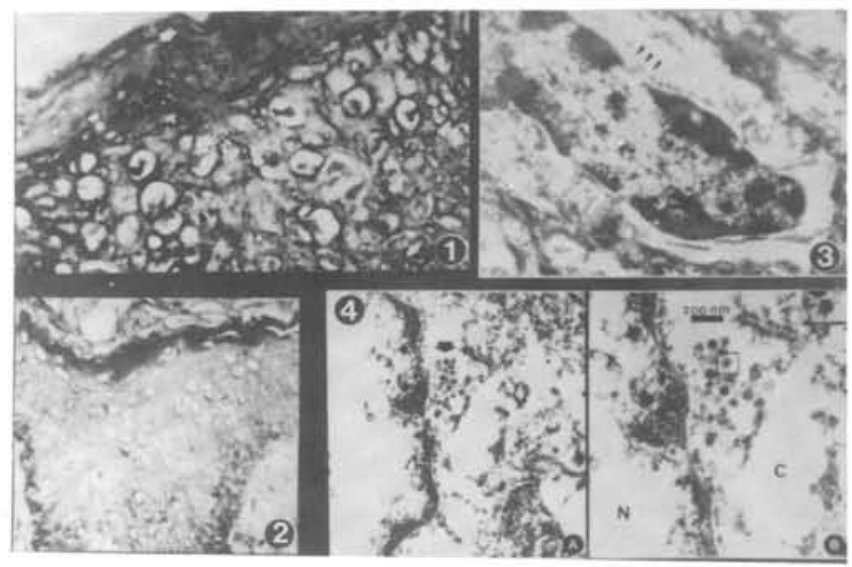

FIGURE 3 - Immuno-Histochemical Aspects and Ultrastructure Nuclear and Cytoplasmic Immunopositivity:

1- Case 2; 2 - Case 4

3 - Disruption of the nuclear membrane () and perinuclear clearance (case $4-15,000 x$ )

4 - Renal tubular cell (case 4):

A. viral particles of $50 \mathrm{~nm}(30,000 \mathrm{x})$

B. particles enlargement $(81,000 \mathrm{x})$ 
The immunopositivity for the Ll protein of the HPV capsid in the nucleus and cytoplasm of the epidermic cells of 4 of the 5 lesions studied and the identification of nuclear and cytoplasmatic viral particles, measuring approximately $50 \mathrm{~nm}$, in the epidermic cells of three lesions, confirm the association between the HPV and the lesions studied. However, only more detailed studies with a greater number of cases can definitely confirm the involvement of the HPV in the etiology of these lesions.

\section{RESUMO}

Introdução: Os autores apresentam um estudo de cinco casos de papilomas e papilomatoses vulvares congênitas em neo e nati-mortos. Material e Métodos: O material utilizado foi proveniente de cinco necrópsias. A avaliação histopatológica mostrou aspectos sugestivos de infecçăo pelo Pailomavirus humano (HPV). A microscopia eletrônica de três dos casos identificou particulas viróticas nucleares e citoplasmáticas variando de 40 a $60 \mathrm{~nm}$, compativeis com HPV. Resultados: O estudo imunohistoquímico destas lesōes demonstrou imunopositividade citoplasmática e nuclear. Conclusāo: Os autores concluiram que a presença de partículas viróticas somada a imunopositividade em células escamosas, sāo evidências do provável envolvimento etiológico do HPV nestas lesōes.

\section{REFERENCES}

1. ORTH, G. et alii. The human papillomaviruses. Bull. Cancer, 65: 151-164, 1978.

2. OSTROW, R.S. \& FARAS, A.J. The molecular biology of Human papillomaviroses and the pathogenesis of genital papillomas and neoplasma. Cancer and Metastasis Review, 6: 383-395, 1987.

3. SYRJANEN, K.J. Epidemiology of Human papillomavirus (HPV) infection and their associations with genital squamous cell cancer. APMIS, 97: 957-970, 1989.

4. DIAS, E.P. Papillomavirus humano: aspectos biológicos, clínicos e morfológicos. JMB, 64 (6): 206-17, 1993.

5. DE JONG, A.R., WEISS, J.C. \& BRENT, R.L. Condyloma acuminata in children. Am. J. Dis. Child., 136 (8): 704-706, August, 1982.

6. TANG, C-k; SHERMETA, D \& WOOD, C Congenital condyloma acuminata. Am. J. Obst. \& Ginecol., 15:912-913, 1978.

7. STUMPF, P.G. Increasing occurrence of condylomata acuminata in premenarchal children. Obst. \& Ginecol., 56 (2): 262-264. 1980.

8. JONES, J.G. Sexual abuse of children. Current concepts. Am. J. Dis. Child., 136 (2): 142-146, 1982.

9. DE JONG, A.R. Sexually transmitted diseases in children. Am. Fam. Physician., 30 (1): 185-193, 1984.

10. STRINGEL, G., MERCER, S. \& CORSINI, L Condyloma acuminata in children. J. Pediatri. Surg., 20 (5) : 499 - 501 , 1985.

11. ROCK, B. et alii. Genital tract papillomavirus infection in children. Arch. Dermatol. 122 (10) :1129-1132, Oct, 1986.

12. BENDER, M.E. New concepts of condyloma acuminata in children. Arch. Dermatol., 122 (10): 1121-1124, Oct, 1986.
13. VALLEJOS, H. et alii. Characterization of Human Papilloma Virus types in condylomata acuminata in children by in situ hybridization. Lab. Invest., 56 (6): 611-615, 1987.

14. STEINBERG, B.M. Papillomavirus. Effects upon mother and child. Ann. N. Y. Acad. Sci., 549 (12): 118-128, 1988.

15. SINGH, K.G., BAJAJ, A.K. \& SHAPMA, R. Perianal condyloma acuminatum in an infant. Int. J. Dermatol., 27 (3): 181-182, 1988.

16. GIBSON, P.E., GARDNER, S.D. \& BEST, S.J. Human papillomavirus types in anogenital warts of children. J. Med. Virol., 30 (2): 142-145, Feb, 1990.

17. BOYD, A.S. Condylomata acuminata in the pediatric population. Am. J. Dis. Child., 144 (7): 817-824, 1990.

18. NUOVO, G.J. et alii. Human papillomavirus segregation patterns in genital and nongenital warts in prepuberal children and adults. Am. J. Clin. Pathol., 95: 467-474, 1991.

19. CRAIGHILL, M.C. Human Papillomavirus Infection in Children and Adolescents. Sem. Pediatr. Infect. Dis., 4 (2): 85-93, 1993.

20. CHACKO, M.R. \& TABER, L.H. Epidemiology of Sexually transmitted Diseases in Children and Adolescents in the United States. Sem. Pediatr. Infect. Dis., 4 (2): 71-76, 1993.

21. HORDING, U. et alii. Prevalence of Human papillomavirus types 11,16 and 18 in cervical swabs. A study of 1362 pregnant women. Eur. J. Obst. et Gynecol. Reprod. Biol., 35 (2-3): 192 8, 1990.

22. BEURET, T., SADOUL, G., FARL, A., IONESCO, M. \& DE BRUX, J. Estude epidemiologique comparative entre 120 patientes atteintes de lesion condylomateuse et 120 patientes temoins. J. Gynecol. Obstet. Biol. Reprod. (Paris), 16 (5): 555-564, 1987.

23. GARRY, R. \& JONES, R. Relationship between cervical condylomata, pregnancy and subclinical papillomavirus infection. J. Reprod. Med., 30 (5): 395-399, 1985.

24. RAYMOND, F.R. \& THOMAS, R.J. Condyloma acuminatum in pregnancy. J. Am. Osteopath. Assoc., 82 (10): 774-778, 1983. 
25. HALLDEN, C. \& MAJMUDAR, B. The relationship between juvenil laryngeal papillomatosis and maternal condylomata acuminata. J. Reprod. Med., 31 (9): 804-807, 1986.

26. KJER, J.J., ELDON, K. \& DREISLER, A. Maternal condylomata and juvenil laryngeal papillomas in their children. Zentralbl. Gynakol., 110 (2): 107-110, 1988.

27. FLETCHER, J.L.Jr. Perinatal transmission of Human papillomavirus. Am. Fam. Physician., 43 (1): 143-8, 1991.

28. CALKINS, J. W., MASTERSON, B.J., MAGRINA, J.F. \& CAPEN, C.V. Management of condylomata acuminata with the carbon dioxide laser. Obstet. Gynecol., 59 (1): 105-108, 1982.

29. BERGMAN, A., MATSUNAGA, J. \& BHATIA, N.N. Cervical cryotherapy for condylomata acuminata during pregnancy. Obstet. Gynecol., 69 (1): 47-50, 1987.

30. MATSUNAGA, J., BERGMAN, A. \& BHATIA, N.N Genital condylomata acuminata in pregnancy: effectiveness, safety and pregnancy outcome following cryotherapy. Br. J. Obstet. Gynecol., 94 (2): 168-172, 1987.

31. AUDRA, P. [The management of pregnant women presenting with genital HPV infections]. Rev. Fr. Gynecol. Obstet., 85 (10): 561-3, 1990.

32. ROGO, K.O. \& NYANSERA, P.N. Congenital condylomata acuminata with meconium staining of amniotic fluid and fetal hydrocephalus: case report. East. Afr. Med. J., 66 (6): 411 413, Jun, 1989.

33. PATSNER, B., BAKER, D.A. \& JAMES, W.O.Jr. Human papillomavirus genital tract infections during pregnancy. Clin. Obstet. and Gynecol., 33 (2): 258-267, 1990.

34. ROMAN, A. \& FIFE K. Human papillomavirus DNA associated with foreskins of normal newborns. L. Infect. Dis., 153: 855, 1986.

35. SEDLACEK, T.V., LINDHEIM, S. Eder, C. et alii. Mechanism for human papillomavirus transmission at birth. Am. J. Obstet. Gynecol., 161: 55, 1989.

36. TSENG, CJ. et alii. - Possible transplacental transmission of human papillomaviruses. Am. J. Obstet. Gynecol., 166: 35 40, 1992.

37. BERGERON, C., FERENCZY, A., RICHART, R.M. \& GURALNICK. M. Micropapillomatosis Labialis appears unrelated to Human papillomavirus. Obstet. Gynecol., 76 (2): 281-286, 1990

38. COSTA, S. et alii. Is vestibular papillomatosis associated with Human papillomavirus? J. Med. Virol., 35: 7-13, 1991.

39. McKAY, M. Vulvite and vulvovaginitis: cutaneous considerations. Am. J. Obstet. Gynecol., 165 (4): 11761182,1991 .

40. MARINOFF, S. C. \& TURNER, M.L.C. Vulvar vestibulitis syndrome: an overview. Am. J. Obstet. Gynecol., 165 (4): 1228$1233,1991$.

41. WILKINSON, E.J. et alii. Vulvar vestibulitis is rarely associated with human papillomavirus infection types $6,11,16$ or 18 . Int. J. Gynecol. Pathol., 12 (4): 344-9, 1993.

42. ORIEL, J.D. Natural history of genital warts. Brit. J. Vener. Dis., 47: 1-13, 1971.

43. BAROUR, S., LINDELVF, B. \& EKLUND, G. Condylomata acuminata and risk of cancer: an epidemiological study. BMJ, 303 (10): 341-344, 1991.

44. AYRE, J.R. The vaginal smear. "Precancer" cell studies using a modified technique. Am. J. Obstet. Gynecol., 58: 1205-1219. 1949.
45. REAGAN, J.W., HICKS, D.J. \& SCOTY, R.B. Atypical hyperplasia of uterine cervix. Cancer, 8: 42-53, 1955.

46. KOSS, L.G. \& DURFEE, G.R > Unusual patterns of squamous epithelium of the uterine cervix: cytologic and pathologic study of koilocytotic atypia. Ann. NY. Acad. Sci., 63: 1245-1261, 1956.

47. ORIEL, J.D. \& ALMEIDA, J.D. Demonstration of virus particles in human genital warts. Brit. J. Vener. Dis., 46: 37-42, 1970.

48. GONZALEZ-ANGULO, A., CHAVEZ, I.R. \& CASTANEDA, M. A reliable method for electron microscopic examination of specific areas from paraffin-embedded tissue mounted on glass slides. Am. Soc. Clin. Pathol., 70 (4): 697-699, 1978.

49. KADISH, A.S., BURK, R.D., KRESS, Y., CALDER S. \& ROMNEY, S. Human Papillomaviruses of different types in precancerous lesions of the uterine cervix: Histologic, Immunocytochemical and ultrastuctural studies. Hum. Pathol., 17: 384-392, 1986.

50. OASHI, M. \& OGIYAMA Y. Electron microscopic examination of cutaneous lesions by the quick rembedding method from paraffin-embedded blocks. J. Cutan. Pathol. 21: 239-246, 1994.

51. WOODRUFF, J.D. et alii. Immunologic identification of papillomavirus antigen in condyloma tissues from the female genital tract. Obstet. Gynecol., 56 (6): 727-732, 1980.

52. GOES JUNIOR, J.S. et alii: Presença de antígenos de papilomavírus em lesões pré-malignas da cérvice uterina no Brasil. Um estudo imuno-histoquímico de 90 casos. Rev. Bras. Ginec. Obstetr., maio/ junho: 128-133, 1983.

53. PADAYACHEE, A. \& Van WYK, W. Human Papillomavirus (HPV) in oral Squamous Cell papillomas. J. Oral. Pathol., 16: 353-355, 1987.

54. ZHOU, J. et alii. Identification of nuclear localization signal of human papillomavirus type $16 \mathrm{~L} 1$ protein. Virology, 185: 625$632,1991$.

55. SADOUL, G. \& BEURET, T. Analyse d'une serie continue de 421 condylomes genitaux. Evolution, conduite et resultats therapeutiques. J. Gynecol. Obstet. Biol. Reprod., 14 (8): 1049 $1058,1985$.

56. GLEW, S. \& STERN, P.L. HLA antigens and cervical carcinoma. Nature, 356: 22, 1992.

57. BARCELLOS, J.M.P. et alii. Colo uterino: estudo na infante, recém-nascida e feto. Alguns aspectos cito e histopatológicos. Rev. Bras. de Cancerologia, 25 (3): 77-95, 1975.

58. MANDAL, D. et alii. Prevalence of occult human papillomavirus infection, determined by cytology and DNA hybridization, in heterosexual men attending a genitourinary medicine clinic. Int. J. STD AIDS, 2 (5): 351-5, 1991.

59. ROBERTSON, D.I. et alii. Cérvico-vaginal screening in an STD clinic. Can. J. Public. Health, 82 (4): 264-6, 1991.

60. MINCHEVA, A. et alii. Detection of human papillomavirus DNA in gynecological swabs by filter in situ hybridization. Acta. Virol. (Praha), 35 (3): 209-17, 1991.

61. NUOVO, G.J. et alii. Human papillomavirus segregation patterns in genital and nongenital warts in prepubertal children and adults. Am. J. Clin. Pathol., 95: 467-474, 1991.

62. REID, R. et alii. Sexually transmitted papillomaviral infections. Am. J. Obstet. Gynecol., 156 (1): 212-222, 1987.

63. WILSON, R.W., CHENGGIS, M.L. \& UNDER, E.R. Longitudinal study of human papillomavirus infection of the female urogenital tract by in situ hybridization. Arch. Pathol. Lab. Med., 114: 155-159, 1990. 